\title{
A simple method to estimate regional yields of biomass crops
}

S. Nonhebel, J. Goudriaan, R. Rabbinge,

Department of Theoretical Production Ecology, Agricultural University Wageningen, PO BOX 430, 6700 AK Wageningen, The Netherlands.

\begin{abstract}
The use of biomass crops as an energy source is frequently mentioned as an option to reduce $\mathrm{CO}_{2}$ emissions. To evaluate the possibilities reliable yield estimates of biomass crops are required. In this paper a simple method is developed to estimate regional yields of various biomass crops, based on the linear relation between intercepted light and biomass production.

The quality of the estimates was studied by using the method to estimate yields of several agricultural crops in two regions in The Netherlands. In general a deviation of less than $10 \%$ was found between actual and estimated average yield.
\end{abstract}

\section{INTRODUCTION}

One of the options to diminish present $\mathrm{CO}_{2}$ emissions is replacing a part of the fossil fuels by energy from crops. During their growth crops capture $\mathrm{CO}_{2}$ which is again released when the crops are used for energy supply. This means that $\mathrm{CO}_{2}$ is recycled. For assessment of the possibilities of this energy source reliable estimates of the yields are required, since the expected yield of an energy crop determines the outcome of the evaluation. Candidate biomass crops (used for electricity production) like willow and miscanthus are not yet grown on a large scale, so that it is difficult to assess their yields. In current energy scenarios and in recent studies of possibilities of using biomass crops as an energy source $(1,2,3)$, the yield estimates are based on a limited number of field experiments and data are used for large areas (sometimes even globally). However, the yield of a crop is strongly determined by its growing conditions and large differences in yields between regions and years are observed. This 
implies that yields obtained in one region in one year cannot easily be translated into yields in other regions or other years. For energy supply not the yield in one particular field is of interest but the amount of energy that can be produced in a region. Therefore yield estimates have to be on a regional rather than on a farm scale. This regional yield cannot be determined in field experiments.

Here a simple method is developed to estimate regional yields of biomass crops. The method is based on knowledge obtained in agricultural research.

\section{METHOD}

Research on various agricultural crops has shown that a linear relation exists between the amount of solar radiation intercepted by the crop and the above ground biomass produced (4). The slope of the line is the so-called Light Use Efficiency (LUE). Under optimal conditions a LUE value of $1.4 \mathrm{~g} \mathrm{MJ}^{-1}$ (global radiation) is found for most agricultural crops, and also for fast growing trees $(4,5)$. This implies that the yield of a crop $\left(\mathrm{Y}_{\mathrm{p}}\right)$ can be calculated by:

$\mathrm{Y}_{\mathrm{p}}=\mathrm{I}_{\text {int }} \times \mathrm{LUE} \times \mathrm{HI}$

in which $\mathrm{I}_{\mathrm{int}}$ is the radiation intercepted during the growing season and $\mathrm{HI}$ is the harvest index (fraction of the total biomass that is harvested). Data of both $\mathrm{HI}$ and $\mathrm{I}_{\text {int }}$ can be derived from literature (6). $\mathrm{Y}_{\mathrm{p}}$ is the production under optimal circumstances (the crop is growing with ample supply of water and nutrients and free from pests, diseases and weeds), it is a measure of what is potentially possible under given conditions In practice conditions are seldom optimal and and actual yields are generally lower than the calculated potential yield. To obtain actual yields, a correction is needed to account for suboptimal growing conditions. The ratio between actual and potential yield can be interpreted as a characteristic for the type of agriculture in a region. Here this ratio will be called the Yield Correction Factor (YCF). The value of the YCF can be determined by using the above described method for an agricultural crop from which yield data are available and divide actual obtained yield $\left(\mathrm{Y}_{\mathrm{a}}\right)$ by calculated potential yield $\left(\mathrm{Y}_{\mathrm{p}}\right)$ :

$\mathrm{YCF}=\frac{\mathrm{Y}_{\mathrm{a}}}{\mathrm{Y}_{\mathrm{p}}}$ 
Estimates for regional crop yields under present growing conditions ( $\mathrm{Y}_{\mathrm{r}}$ ) can be obtained by using eq 3

$\mathrm{Y}_{\mathrm{r}}=\mathrm{Y}_{\mathrm{p}} \times \mathrm{YCF}$

\section{RESULTS AND DISCUSSION}

\subsection{Determination YCF for two different regions}

In The Netherlands potatoes are planted in April and the crop is harvested in September (7). The total amount of global radiation intercepted by the crop is about $1400 \mathrm{MJ} \mathrm{m}^{-2}$. Using eq 1 leads to a potato yield of 15.0 ton ha-1 (HI of a potato crop is 0.75 ). In 1992 the actual potato yield in Flevopolders (region 1, fig 1) was 10.6 ton $\mathrm{ha}^{-1}$ and in Veenkoloniën (region 2, fig 1) it was 8.6 ton $\mathrm{ha}^{-1}$ (dry matter) (8). Applying eq. 2 results in a YCF for region 1 (YCF $_{1}$ ) of 0.71 and for region $2\left(\mathrm{YCF}_{2}\right)$ of 0.56 .

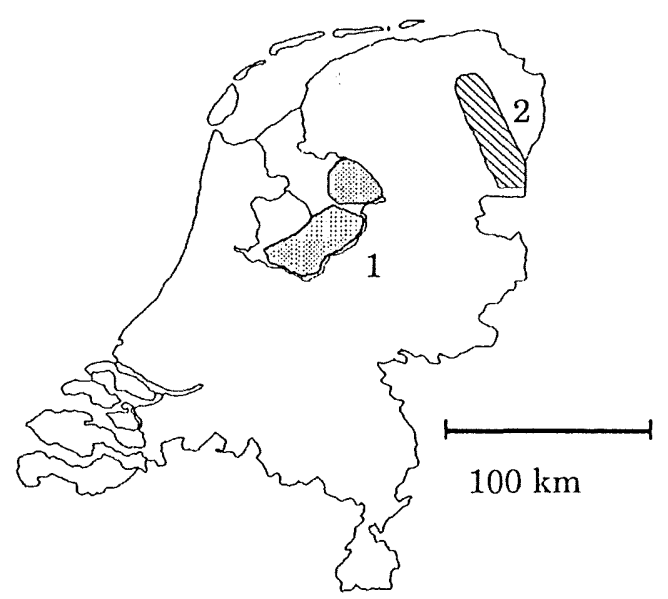

Figure 1. Location of the regions mentioned in text. 


\subsection{Regional yields of agricultural crops}

Since there are no data on average regional yields for biomass crops, the validation possibilities for the method are limited. The only available averages are those from the present agricultural crops. The method described above was used to estimate yields of three agricultural crops and the results were compared with actual average yields obtained in the two regions in 1992 (table 1).

Table 1

Comparison between actual yields $\left(\mathrm{Y}_{\mathrm{a}}\right)$ of agricultural crops and estimated yields $\left(\mathrm{Y}_{\mathrm{r}}\right)$ for two different regions, $\mathrm{YCF}_{1}=0.71$ and $\mathrm{YCF}_{2}=$ 0.56. Deviation (dev in $\%$ of $\mathrm{Y}_{\mathrm{a}}$ ) is also given.

Yields (harvestable biomass) in ton dry matter ha-1.

\begin{tabular}{lrrrrrrr}
\hline & region 1 & \multicolumn{5}{c}{ region 2} \\
\hline crop & $\mathrm{Y}_{\mathrm{r}}$ & $\mathrm{Y}_{\mathrm{a}}$ & dev. & $\mathrm{Y}_{\mathrm{r}}$ & $\mathrm{Y}_{\mathrm{a}}$ & dev. \\
\hline winter wheat & 7.6 & 7.3 & $4 \%$ & 6.1 & 5.4 & $13 \%$ \\
sugar beet & 15.1 & 15.4 & $2 \%$ & 12.3 & 12.0 & $3 \%$ \\
maize & 14.6 & 15.4 & $5 \%$ & 11.9 & 13.2 & $10 \%$ \\
\hline
\end{tabular}

The deviation between simulated and actual yields was not large, which shows that the method is a suitable tool for estimating crop yields.

\subsection{Regional yields of biomass crops}

The application of the YCF for biomass crops assumes that knowledge on how to grow such a crop is comparable to that of an agricultural crop. However for the potential biomass crops this is not yet the case. So it is likely that the regional yields of these crops will be lower than calculated here. Further uncertainties exist with respect to values of intercepted radiation and harvest index of the biomass crops. This means that the yield data used for the biomass crops are only indicative. However, it can be concluded that the potential biomass production of ' $a$ ' perennial biomass crop lies between 18 and 
22 ton ha-1. Present regional averages of these crops would be $13-15$ ton $\mathrm{ha}^{-1}$ for the high yielding regions and 10-12 ton ha-1 for the low yielding regions in The Netherlands (table 2). Estimates of biomass crops yields given in literature for present conditions are 10-12 ton $\mathrm{ha}^{-1}(1,9)$ which agree with values found here.

The value of YCF is time and space dependent and must be determined for each region individually. It is likely that YCF values in other regions in Europe will be much lower due to less well developed agriculture which will result in lower yields.

To improve yield estimates, detailed field experiments are required to obtain more information on light interception and harvest index of candidate biomass crops.

Table 2

The calculated potential yield $\left(\mathrm{Y}_{\mathrm{p}}\right)$ and the regional yields (harvested biomass, in ton (dry matter) ha-1) of three candidate biomass crops in two regions $\left(\mathrm{Y}_{\mathrm{r} 1}, \mathrm{Y}_{\mathrm{r} 2}\right)$. YCF $1=0.71$ and $\mathrm{YCF}_{2}=0.56$. Yields (harvested material) in ton (dry matter) ha ${ }^{-1}$.

\begin{tabular}{lllll}
\hline Crop & $\begin{array}{l}\text { harvested } \\
\text { parts }\end{array}$ & $\mathrm{Y}_{\mathrm{p}}$ & $\mathrm{Y}_{\mathrm{r} 1}$ & $\mathrm{Y}_{\mathrm{r} 2}$ \\
\hline Miscanthus & stems & 21.9 & 15.3 & 12.3 \\
Poplar & stems/branches & 18.0 & 12.6 & 10.0 \\
Willow & stem/branches & 19.6 & 13.7 & 11.0 \\
\hline
\end{tabular}

\section{CONCLUSIONS}

Based on the result that yields of agricultural crops are estimated with an inaccuracy of $10 \%$, it is concluded that the estimation method described can be a useful tool in research on the possibilities of using biomass crops for energy supply. Estimated biomass crops yields are 10-15 ton ha-1 under present conditions in The Netherlands. 


\section{Acknowledgement}

This work was funded by the Dutch National Research Program on Global Air Pollution and Climate Change Project nr 853117

\section{REFERENCES}

1 Hall, D.O., et al.,1993. In: Johansson, T.B., Kelly, H., Reddy, A.K.N., Williams, R.H. (eds) Renewable Energy, Island Press, Washington, pp 593651.

2 Okken, P.A., Ybema, J.R., Kram, T., Lako, P., Gerbers, D., 1994. Energy systems and $\mathrm{CO}_{2}$ constraints. Netherlands Energy Research Foundation, Petten, The Netherlands.

3 Lysen E.H, et al., 1992. De haalbaarheid van de productie van biomassa voor de Nederlandse energie huishouding. Novem, Apeldoorn. (in Dutch)

4 Monteith, J.L., 1977. , Phil. Trans.R. Soc. Lond. 282, 277-294.

5 Cannell, M.G.R. 1989. Scand. J. For. Res. 4, 459-490.

6 Nonhebel, S. 1994.,A simple model to estimate regionally average yields of biomass crops, submitted to Biomass and Bioenergy

7 Jong, J.A.,1985, De teelt van aardappelen,Drachten (in Dutch).

8 PAGV, 1993. Kwantitatieve informatie voor de akkerbouw en de groenteteelt in de vollegrond, 1993-1994, PAGV, Lelystad (in Dutch).

9 Christersson, L.et al, 1993. The Forest Chronicle 69, 687-693. 